Biografistyka Pedagogiczna

Rok 1 (2016) nr 1

ISSN 2543-6112; e-ISSN 2543-7399

DOI: 10.36578/BP.2016.01.10

Anna Kowalska-Pietrzak*

\title{
Wyobcowania i wykluczenia w dynastii Piastów jako czynnik polityczny
}

\section{Alienation and Exclusion inside the Piast Dynasty as a Political Factor}

\begin{abstract}
This paper presents the political effects of the alienation and exclusion of the Piast dynasty members. It shows how fathers and stepmothers treated children from previous marriages. It demonstrates the importance of alienated and excluded royal ancestors to the medieval state.
\end{abstract}

Keywords: Piast dynasty, exclusion, alienation, Middle Ages, dynastic politics

Przedmiot rozważań niniejszego artykułu stanowią przykłady wyobcowań i wykluczeń dzieci z dynastii Piastów do schyłku XII w. Analizie poddane zostały relacje między młodymi książętami a ojcami i/lub macochami, którzy swoim postępowaniem wobec dzieci przyczynili się do wywołania buntów oraz walk, a w ten sposób doprowadzili do przekształceń politycznych w państwie. Jest to również jeden z przyczynków w badaniach z obszaru psychologii historycznej.

Uczeni uznają, iż trudno jest precyzyjnie zdefiniować pojęcie psychologii historycznej, ze względu na szeroki i mało wyraźny zakres tego terminu1. Jako jedna z wielu występuje definicja wyjaśniająca, iż pod tym pojęciem kryje się uzupełnienie tradycyjnej psychologii dotyczącej człowieka współczesnego o badania nad zachowaniami oraz ich

* Anna Kowalska-Pietrzak - dr hab., adiunkt w Instytucie Historii Uniwersytetu Łódzkiego, anna.kowalska@uni.lodz.pl.

1 Z. Spendel, Podmiotowość człowieka a psychologia historyczna, Katowice 1994, s. 41. 
źródłami u człowieka w przeszłości ${ }^{2}$. Psychohistoria jest też definiowana: „Jako nauka o motywacji w historii, psychohistoria może koncentrować się na tych samych wydarzeniach dziejowych, którymi zajmuje się historia, ale jej celem nie będzie przedstawienie tego, co zdarzyło się dzień po dniu", a jako przedmiot badań uwzględnia również takie elementy jak choćby historię dzieciństwa ${ }^{3}$. Jest też „nie tyle odkrywaniem, ile odkrywaniem ponownym - to proces stwierdzania, co faktycznie już wiemy" ${ }^{\prime 4}$.

Definiując w ten sposób przedmiot badań psychohistorii, stwierdzić można, iż już na początku dziejów pierwszej polskiej dynastii rysuje się wizerunek macochy, która chce zapewnić swoim synom, przychodzącym na świat w latach ok. 979-986 ${ }^{5}$, panowanie po śmierci ich ojca, zabezpieczając swoich potomków przed przyrodnim bratem. W rodzinie książęcej można byłoby w ten sposób dostrzec podziały na „starą” i „nową" rodzinę księcia Mieszka I, który darząc ciepłymi uczuciami swoich młodszych potomków, zrodzonych z drugiej żony Ody, mógłby posunąć się do wydzielenia im, jako przyszłego władztwa, terenów tzw. civitas Schinesghe. Jego syn Bolesław urodzony z pierwszego małżeństwa z czeską Dobrawą, pominięty w dokumencie Dagome iudex, panowałby wówczas w Krakowie. Historycy, interpretując pominięcie Chrobrego w Dagome iudex jako jego wydziedziczenie, dopatrywali się często wpływów Ody na zapewne już pragnącego spokoju i podstarzałego męża. Czy jednak taka interpretacja nie wymagałaby spojrzenia na Mieszka jako władcę, który zmęczony panowaniem, stracił ostrość umysłu i przewidywania, iż taka sytuacja może mieć zdecydowanie negatywny wpływ na przyszłość jego państwa? ${ }^{6}$ Czy faktycznie książę nie przewidział, podobnie jak żyjący 150 lat później Bolesław Krzywousty, że jego potom-

2 Tamże, s. 44 i nast. O zagadnieniach związanych z psychohistorią, dyskusją wokół jej definiowania i przedmiocie badań zob. również: Z. Barbu, Problems of Historical Psychology, London 1960; M. Dymkowski, Między psychologią a historia. O roli złudzeń w dziejach, Warszawa 2000; tenże, Wprowadzenie do psychologii historycznej, Gdańsk 2003; T. Pawelec, Wprowadzenie: psychohistoria w poszukiwaniu tożsamości, w: Psyche i Klio. Historia w oczach psychohistoryków, wybór, przekład i wstęp T. Pawelec, Lublin 2002, s. 11-31; B. Mazlish, Podejście psychohistoryczne, w: Psyche i Klio, s. 35-50; Th. A. Kohut, Psychohistoria jako historia, w: Psyche i Klio, s. 73-94; P.C. Hoffer, Czy psychohistoria jest naprawdę historia??, w: Psyche i Klio, s. 95-110.

3 L. de Mause, Niezależność psychohistorii, w: Psyche i Klio, s. 52.

4 Tamże, s. 72.

5 K. Jasiński, Rodowód pierwszych Piastów, Poznań 2004, s. 100, 101, 104.

6 J.Strzelczyk, Mieszko Pierwszy, Poznań 1999, s. 181-182. Przypuszczenia o roli Ody jako doradczyni męża w ostatnich latach jego panowania wysuwał m.in. S. Zakrzewski, Mieszko I jako budowniczy państwa polskiego, Kraków 2006, s. 117. 
kowie nie poprzestaną na przydzielonych sobie władztwach? Patrząc z perspektywy czasu, Mieszko mógł mieć do tego większe prawo niż jego prapraprawnuk Bolesław, który znał dzieje dynastii i sam brał udział w rywalizacjach politycznych i militarnych w ramach sporów dynastycznych. Nie można też wykluczyć, że Bolesław Chrobry, który miał mniej niż 15 lat, gdy został pasierbem i przyrodnim bratem, wewnętrznie przygotowywał się do mającej nastąpić w przyszłości rozgrywki. Czy zachowanie jego ojca mogło wskazywać na okazywanie większego zainteresowania młodszym synom niż jemu - pierworodnemu, który widział się w roli dziedzica? Czy Bolesław po powtórnym ożenku księcia czuł się odsunięty, czy też jego relacje z ojcem nie uległy zmianie? Tego ze źródeł nie wiemy. Wiemy natomiast, że po śmierci ojca i wypędzeniu macochy objął panowanie na terenach całego państwa.

Swemu pierworodnemu synowi Bolesław zgotował trudny los, jeśli pozostaniemy przy tradycyjnej interpretacji dziejów Bezpryma. Frapująca jest bowiem historia życia najstarszego syna Chrobrego, który przez kolejne stulecia uchodził za dziecko niechciane, wręcz wykluczone z rodziny. Jednak ostatnio jego losy uległy reinterpretacji Historycy próbowali udowodniać jego wykluczenie już przez interpretację samego imienia. Imię Bezprym (ur. 986) miałoby być nadawane dzieciom niechcianym i sam fakt nazwania nim syna wykluczałby go jako członka dynastii i dziedzica. Stawiano też hipotezy, że matka Bezpryma została odesłana przez męża, gdyż nie przypadła mu do gustu. Jest to jednak mało prawdopodobne, aby uczucia, a nie polityka mogły zaważyć na tak ważnej decyzji, jaką było zerwanie małżeństwa. Bezprym pozostał zapewne wówczas, już bez matki, na dworze ojca, gdyż jako pierworodny syn i kandydat na następcę tronu, przebywając za granicą, mógłby zagrażać Polsce, stając się narzędziem w rękach obcych?.

Bezprym wychowywany był więc bez matki niemal od kołyski. Czy wzrastał w poczuciu osamotnienia, bez ciepłych uczuć ojcowskich? Na to pytanie przez dziesięciolecia udzielano twierdzącej odpowiedzi ${ }^{10}$. Tak interpretując jego losy, opisywano wydarzenia z historii Polski jako wynik m.in. wieloletniego wyobcowania Bezpryma, który

7 B. Śliwiński, Bezprym. Pierworodny syn pierwszego króla Polski (986-zima/wiosna 1032), Kraków 2014.

8 Szeroko o imieniu pisze Błażej Śliwiński; tamże, s. 50 i nast. Autor przedstawia m.in. dowody na inne możliwości interpretacyjne tegoż imienia niż tylko osoby niechcianej i nielubianej.

9 Tamże, s. 58-59.

10 K. Szajnocha, Bolesław Chrobry i odrodzenie sie Polski za Władysława Łokietka. Dwa opowiadania historyczne, Lwów 1859, s. 227; inaczej B. Śliwiński, Bezprym, s. 92. 
oczekiwał na moment, gdy będzie mógł odpłacić młodszemu, przyrodniemu bratu za lata odsunięcia od dworu ojcowskiego i braku nadziei na odziedziczenie tronu. Jego wykluczenie z rodziny byłoby więc jednym z ważnych elementów kryzysu monarchii pierwszych Piastów. Jakiej reinterpretacji może ulec ocena postępowania i udziału najstarszego syna Chrobrego w tych wydarzeniach, jeśli zrezygnujemy z wielowiekowej tradycji, mówiącej o wykluczeniu Bezpryma i zgodzimy się z badaniami Błażeja Śliwińskiego, iż z jedynego źródła, na którym historycy budowali swoje teorie o oddaniu go przez ojca do eremu, wynika, że Bezprym dobrowolnie i samodzielnie, a nawet spontanicznie podjął decyzję o rezygnacji z życia świeckiego? ${ }^{11}$ Taka zmiana postrzegania okoliczności wstąpienia młodego księcia do eremu pociąga za sobą kolejne i pobudza do stawiania następnych pytań. Jedno z najważniejszych brzmi: czy pokolenia badaczy krzywdziły Bolesława i jego trzecią żonę Emnildę, uznając ich za parę przedkładającą wspólne dzieci, a zwłaszcza syna Mieszka (ur. 990), ponad pierworodnego polskiego księcia urodzonego z wcześniejszego związku? Jeśli imię Bezprym może mieć pozytywny wydźwięk, a decyzja księcia o wstąpieniu do eremu była niezależna od woli Bolesława, czy można uznać Chrobrego za ojca, który niemal od narodzin pierwszego syna planował jego odsunięcie od władzy? Nawet jeśli nie darzył syna ciepłymi uczuciami, nie mógł mieć przecież wtedy absolutnej pewności, że doczeka się kolejnego męskiego potomka z następnego małżeństwa. Czy w takim razie można dopatrywać się w Emnildzie modelowej macochy, dążącej do zapewnienia swojemu synowi następstwa tronu? Często w taki właśnie schemat ją wpisywano, dodając, iż jej wpływ na męża mógł doprowadzić do ostatecznego wykluczenia Bezpryma ${ }^{12}$. Część historyków uznaje jednak, że taki wizerunek księżnej nie byłby zgodny z jej kronikarskimi opisami, jako kobiety dobrej i miłosiernej, o zbawiennym wręcz wpływie na męża ${ }^{13}$. Czy w przypadku kwestii kluczowych w rodach panujących, czyli przy sprawach następstwa tronu, w sercu Emnildy, nad współczuciem dla pasierba, górę wzięły jednak uczucia księżnej-matki? Czy Bolesław faktycznie podjął decyzję o przekazaniu

11 Z Damianiego żywotu św. Romualda, wyd. A. Bielowski, w: Monumenta Poloniae Historica [dalej: MPH], Lwów 1864, s. 326; B. Śliwiński, Bezprym, s. 95.

12 S. Łaguna, Rodowód Piastów, „Kwartalnik Historyczny”, 11 (1897) s. 758; B. Zientara, Mieszko II, w: Poczet królów i książąt polskich, red. A. Garlicki, Warszawa 1998, s. 36; Poglądy historiograficzne na ten temat zebrał B. Śliwiński, Bezprym, s. 92-95.

13 Galli Anonymi cronicae et gesta ducum sive principum Polonorum, wyd. K. Maleczyński, w: MPH, t. 2, Kraków 1952, I, 13; S. Zakrzewski, Bolesław Chrobry Wielki, Kraków 2006, s. 321-322. 
tronu Mieszkowi ze względu na głęboką więź emocjonalną z jego matką, a tym samym przedkładanie jego osoby nad pierworodnego syna, z matką którego mogło nie łączyć go żadne szczególnie pozytywne uczucie? Czy rzeczywiście, jak pisał Joachim Lelewel: Mieszko zwyciężył „przez predylekcje ojca do płodu serdecznie umiłowanej Emnildy"? ${ }^{14}$ Tego, mimo wielu innych uwarunkowań, też nie można zupełnie wykluczyć. A jeśli rację mieli ci badacze, którzy uznawali, że Bolesław mógł po śmierci Emnildy (1017), nawet gdyby za jej życia faworyzował Mieszka, zmienić swoje poglądy na temat Bezpryma i przekazać mu władzę? A może jednak faktycznie Bezprym wzrastał przez wszystkie lata w poczuciu krzywdy i niechęci do ojca, co czyniło go naturalnym ogniwem, wokół którego skupiała się opozycja ${ }^{15}$, i na zmiany w jego dorosłym życiu było już za późno. Niezależnie od okoliczności i oceny wydarzeń, nie można nie zgodzić się ze stwierdzeniem, że Bezprym był postacią tragiczną ${ }^{16}$.

Wspomniany wyżej wątek klasztorny wpisuje się w losy kolejnego potomka Piastów, który miał macochy. Dodatkowo historiografia niezbyt pochlebnie wypowiadała się o jego ojcu, przedstawiając go w pewnym okresie jego życia jako człowieka, którego „Jedynym świadectwem aktywności [...], można rzec z sarkazmem, był syn Zbigniew $^{\prime \prime 17}$. W tym miejscu można też postawić pytanie, jaki wpływ na losy Zbigniewa (ur. ok. 1070-1073) ${ }^{18}$, syna Władysława Hermana - najpierw jako dziecka, a później dorosłego człowieka oraz na jego działania - miał fakt, iż jego matka nie pochodziła z rodu panującego. Przez kronikarza, piszącego ok. 30-40 lat po tych wydarzeniach, nie była ona przedstawiana jako książęca żona, ale została określona jako concubina. Termin ten mógł oznaczać wówczas każdą kobietę niepozostającą w związku sakramentalnym $^{19}$. Czy taka relacja Galla Anonima mogła wynikać z chęci przedstawienia jej syna w gorszym świetle niż potomka zrodzonego z księżniczki czeskiej Judyty, poślubionej później przez Władysława Hermana? ${ }^{20}$ A może bezimienna matka Zbigniewa była

14 J. Lelewel, Polska wieków średnich, t. 4, Poznań 1851, s. 45.

15 S. Zakrzewski, Bolesław, s. 322.

16 J. Strzelczyk, Bolesław Chrobry, Poznań 1999, s. 247.

17 K. Benyskiewicz, Książę Polski Władysław I Herman 1079-1102, Zielona Góra 2010, s. 72. Ze starszej literatury: T. Tyc, Zbigniew i Bolesław, w: tenże, Z dziejów Wielkopolski i Pomorza. Wybór prac, red. i posłowie J. M. Piskorski, Poznań 1997; R. Grodecki, Zbigniew ksiąze Polski, w: Studja staropolskie ku czci Aleksandra Brücknera, Kraków 1928.

18 K. Jasiński, Rodowód pierwszych Piastów, s. 182.

19 Galli Anonymi, II, 4.

20 A. Krawiec, Król bez korony. Władysław I Herman, książę Polski, Warszawa 2014, s. 31. 
książęcą małżonką, nawet jeśli poślubioną tylko zgodnie z dawnym zwyczajem, lecz po jej śmierci zaczęto mówić o niej jako o książęcej konkubinie? ${ }^{21}$ O nierówności pochodzenia małżonków badacze piszą niekiedy jako o największej słabości tego związku²2. Czy rzeczywiście jedynym powodem takiego postępowania była kwestia obniżenia rangi Zbigniewa wobec jego młodszego, przyrodniego brata, czyli Bolesława zwanego później Krzywoustym. Jeśli faktycznie concubina już nie żyła, nawet gdy pochodziła z niższego stanu, nie mogła zagrażać w żaden sposób nowej małżonce, niezależnie od tego, czy związana była z księciem w sposób formalny czy nieformalny. Pozostawałaby więc tylko kwestia pozycji jej syna.

Niekiedy zwraca się też uwagę, podobnie jak w przypadku Bezpryma, na sam fakt nadania Zbigniewowi imienia wcześniej nieznanego w rodzie Piastów. To miałoby od chwili jego narodzin wskazywać na gorszą jego pozycję niż potomków zrodzonych z następnych książęcych związków ${ }^{23}$. Nic jednak nie wskazuje na słabą pozycję Zbigniewa od dnia narodzin. Władysław Herman nie odsunął syna, wychowywał go na swoim dworze, pasował na rycerza i planował dla niego świeckie życie, skoro odesłał go na naukę - najpierw do Krakowa, a potem do Kwedlinburga - dopiero jako kilkunastoletniego młodzieńca, mając już młodszego syna ${ }^{24}$. Gdy urodził się Zbigniew, w Polsce panował wciąż Bolesław Śmiały i Władysław Herman nie mógł wówczas mieć pewności, że przejmie rządy po bracie, który zresztą miał dziedzica Mieszka ${ }^{25}$, urodzonego w 1069 r., a więc starszego od Zbigniewa. Ojciec Zbigniewa nie mógł mieć też pewności, że na świat przyjdą kolejni jego synowie. Dlaczego miałby więc od początku mieć negatywny stosunek do Zbigniewa?

Faktem jest, iż Władysław Herman wchodził w kolejne związki małżeńskie z kobietami o coraz wyższym pochodzeniu. Najpierw była to zapewne dziewczyna z jednego z polskich rodów możnowładczych, być może wielkopolskich lub mazowieckich, bo tam swoją siedzibę miał młody książę, potem księżniczka czeska Judyta, córka Wratysława II, a po jej śmierci Judyta Salicka, córka cesarza Henryka III i sio-

21 Szerzej: S. Rosik, Bolesław Krzywousty, Wrocław 2013, s. 53 i nast.

22 G. Labuda, Zbygniew, w: Stownik starożytności słowiańskich, t. 7, Wrocław 1982, s. 108.

23 K. Jasiński, Rodowód pierwszych Piastów, s. 163.

24 Galli Anonymi, II, 4.

25 O Mieszku: K. Benyskiewicz, Mieszko Bolesławowic 1069-1089. Źródła i tradycja historiograficzna, Kraków 2005. 
stra Henryka IV, wdowa po królu węgierskim Salomonie ${ }^{26}$. To właśnie tej ostatniej żonie Hermana przypisuje się negatywny stosunek do starszego pasierba. Pierwsza z macoch Zbigniewa, Judyta czeska, przez kilka pierwszych lat małżeństwa nie urodziła Władysławowi żadnego potomka. Bolesław Krzywousty przyszedł na świat dopiero po wysłaniu, opisanego obrazowo przez kronikarza, poselstwa do opactwa św. Idziego w Prowansji. Nie miała więc odpowiedniej pozycji, aby mogła snuć intrygi przeciwko pasierbowi. Zmarła zaś w 1086 r., w 4 miesiące po narodzinach syna. Nieco podobna była sytuacja drugiej macochy Zbigniewa. Co prawda urodziła ona Hermanowi 3 córki i to zapewne w pierwszych latach ich małżeństwa (1089-1092), ale nie dała mu syna ${ }^{27}$. Co więcej, wychodziła za mąż jako bezdzietna ponad czterdziestoletnia wdowa, w chwili ślubu w ogóle nie przypuszczano więc, żeby w tym związku mogło pojawić się jakieś potomstwo. Wydawałoby się więc, że i ona nie miała dobrej pozycji przetargowej, aby wyeliminować pasierba. Ale była ona córką i siostrą cesarzy. Znany jest też pogląd, iż w zmowie z potężnym palatynem Sieciechem chciała pozbyć się stopniowo obu pasierbów, aby przejąć władzę po mężu ${ }^{28}$.

Niektórzy badacze uznają, iż sprawa następstwa tronu polskiego rozstrzygnięta została być może już w $1088 \mathrm{r}^{29}$, czyli krótko po ślubie Judyty Salickiej z Hermanem lub nawet jeszcze przed nim, jeśli przyjmiemy, że nastąpił on dopiero w 1089 r. Mogłoby mieć to związek również z usunięciem Mieszka, syna Bolesława Śmiałego. Jeśli tak było, to wskazywałoby to na torowanie drogi do tronu, jeśli nie dla Bolesława Krzywoustego, to może dla Sieciecha, gdyż na potomstwo ze związku z Judytą Salicką, czyli na cesarskie wnuczęta, biorąc pod uwagę powyższe uwarunkowania, Herman nie mógł raczej wówczas liczyć. Sytuacja mogła ulec zmianie dopiero po narodzinach pierwszej córki, a więc w 1089 r. Może wraz z tymi narodzinami obudziła się w Judycie nadzieja

26 Judyta Salicka ma opinię kobiety, która nie odznaczała się szczególnie cnotą wierności małżeńskiej. Przypisuje się jej romanse już jako królowej węgierskiej, a później związki z palatynem Sieciechem. Czy fakt, iż była ona siostrą cioteczną słynnego z życia rozwiązłego i pełnego przygód miłosnych Wilhelma IX Akwitańskiego, nazywanego Trubadurem, może mieć jakieś znaczenie dla wyjaśnienia podłoża przypisywanego jej temperamentu?

27 K. Jasiński, Rodowód pierwszych Piastów, s. 169.

28 Szerzej o poglądach na temat charakteru relacji Judyty i Sieciecha: S. Rosik, Bolesław Krzywousty, s. 48 i nast.; G. Pac, Kobiety z dynastii Piastów. Rola społeczna piastowskich żon i córek do połowy XII wieku - studium porównawcze, Toruń 2013, s. 152 i n.

29 A. Krawiec, Król bez korony, s. 139. 
na przyjście na świat męskiego potomka, któremu zapewni tron. Zacząć jednak trzeba było od walki o rzekome prawa dla młodszego pasierba, którego można byłoby ewentualnie później wyeliminować? Czy jednocześnie mogłoby to potwierdzać przypuszczenie, że Władysław Herman w chwili narodzin cesarskiego wnuka nie miałby skrupułów, aby wydziedziczyć Bolesława tak, jak uczynił to ze Zbigniewem? ${ }^{30}$ Czy faktycznie nie sprawiłoby Hermanowi kłopotów wydziedziczanie po kolei swoich synów, na rzecz ich młodszych braci, rodzących się z coraz to „ważniejszych” małżonek? Ale jednocześnie, jak konkludował Adam Krawiec, Władysław Herman nie był pozbawiony ojcowskich uczuć, gdyż nie kazał zabić Zbigniewa, tylko odesłał go z kraju $u^{31}$. I tu należy zauważyć rzecz bezcenną. Podchodząc w ten sposób do problemu uczuć rodzicielskich, koniecznie trzeba stwierdzić, iż Piastowie nie zabijali swoich potomków. Jeśli z jakiś wzgllędów byli oni niewygodni, znajdowano inne rozwiązanie niż pozbawianie życia własnych synów, np. przeznaczenie ich do stanu duchownego lub wydzielanie im jakiejś części dziedzictwa. To ostatnie rozwiązanie stosowano od czasów Mieszka I i od tego momentu wiadome było, iż się ono nie sprawdza, powodując walki wewnętrzne. Mimo to na taki wariant zdecydował się także Bolesław Krzywousty, do czasów którego każdy panujący Piast, z wyjątkiem Kazimierza Odnowiciela, miał męskie rodzeństwo ${ }^{32}$. Krzywousty musiał więc doskonale znać dzieje własnej dynastii i historię braterskich relacji, których cząstkę sam stanowił.

Wracając do kwestii Zbigniewa, stwierdzić należy, że sprawa jego odsunięcia została dobrze przemyślana, skoro znalazł się on w klasztorze, którego przeoryszą była siostra Judyty, Adelajda. Mogła ona więc dopilnować siostrzanego pasierba. Tak więc, jak słusznie sądzą badacze, wysłanie Zbigniewa poza granice państwa wskazuje na chęć pozbycia się go z kraju, w którym, jak się wkrótce okazało, miał grono zwolenników. Konsekwencją wykluczenia Zbigniewa od praw do władzy był jego bunt. Zbigniew, mimo nadzoru, powrócił do kraju, a ojciec zgodził się na wydzielenie mu części dziedzictwa. Jak jednak wiadomo, nie było to finalne rozwiązanie spraw.

30 Tamże.

31 Tamże.

32 Chociaż część badaczy uznaje, iż miał on brata zrodzonego z konkubiny Mieszka II. Owym bratem miał być Bolesław Zapomniany. Szerzej: G. Labuda, Mieszko II król Polski (10251034). Czasy przełomu w dziejach państwa polskiego, Kraków 1992, s. 147-183. Nie zawsze też sprawdzał się pierwszy wariant, czyli przeznaczenie do stanu duchownego. Na przykład w XIII w. Konrad, syn Henryka Pobożnego, porzucił sutannę i rozpoczął, zakończoną sukcesem, walkę o swoje własne księstwo. 
Zbigniew miał macochę, jego młodszy brat Bolesław miał macochę, miał ją też najstarszy syn Bolesława, czyli Władysław zwany w przyszłości Wygnańcem (ur. 1105) 33 . Kronikarze przedstawiali Władysława w negatywnym świetle, jako człowieka o złych cechach. Niektórzy próbują interpretować takie oceny, biorąc pod uwagę dzieciństwo i młodość księcia, który niechybnie rósł ze świadomością powiększającej się nowej rodziny ojca, a przede wszystkim obserwował wzrastanie swoich młodszych przyrodnich braci, przychodzących na świat od ok. 1120 r. Taka liczba książęcych synów musiała spowodować, iż na długo przed osiągnięciem przez nich wieku dojrzałego toczyły się rozmowy o przyszłości państwa i młodych dziedziców. Władysław, już jako dorosły człowiek, musiał mieć świadomość, że ojciec nie przewiduje go na jedynego władcę oraz że będzie musiał podzielić się państwem i władzą z młodszymi. A nawet prawna regulacja nie mogła mu zagwarantować sukcesji. Władysław znał historię swojego rodu.

Pojawia się pytanie o postawę jego macochy, czyli Salomei z Bergu. Niekiedy przypisuje się jej rolę niemal twórczyni statutu, który wszedł w życie po śmierci Krzywoustego. Miała ona przyczynić się do jego powstania, oczywiście przez swoje intrygi i przypominanie mężowi o potrzebie zapewnienia dziedzictwa ich synom ${ }^{34}$. Czy jednak nie jest to krzywdzenie Salomei? Podobnie, jak można przypuszczać, krzywdzono Emnildę, gdy przypisywano jej namawianie męża do zabezpieczenia interesów własnego syna? A jeśli spojrzeć na problem z innej strony, to może okazać się, że ustawa miała zabezpieczać prawa najstarszego z synów książęcych, czyli właśnie Władysława. Krzywousty zadbałby więc o swojego pierworodnego ${ }^{35}$. Co prawda ze względu na większą liczbę męskich potomków, Bolesław wydzielił więcej dzielnic, lecz zwiększył rolę stołecznego Krakowa, który otrzymał właśnie najstarszy z synów. Naturalna wydaje się też troska Bolesława i Salomei o zabezpieczenie swoich synów. Nie trzeba mieć wyjątkowego zmysłu, aby dostrzec, iż po śmierci Bolesława Krzywoustego nastąpi problem z sukcesją. Spoglądając na rodzinę Krzywoustego jako na całość, nie widać ani ojcowskiego wykluczenia Władysława, ani intryg macochy. Pozostaje jednak kwestia uczuć Władysława, który mógł patrzeć zupełnie inaczej na rodzinne sprawy i czuć się pokrzywdzonym, gdy z pozycji jedynego dziedzica, w której wzrastał przynajmniej przez pierwszych 10 lat swojego życia, stał się jednym z wielu. Na dodatek żył chyba

33 Biografia Władysława: W. Dworschatschek, Władysław II Wygnaniec, Wrocław 1998.

34 K. Maleczyński, Bolesław III Krzywousty, Kraków 2010, s. 368.

35 W. Dworschatschek, Władysław, s. 28. 
jednak z poczuciem wyobcowania wśród braci zrodzonych z innej matki, kolejnej żony ojca. Jeśli dodamy do tego małżeństwo z krewną cesarską Agnieszką i uznamy jej kronikarski obraz - kobiety ambitnej i pragnącej władzy - za prawdziwy, to naturalne wydaje się, iż Władysław odczuwał potrzebę zwiększenia zakresu swojej władzy. A może również towarzyszyła mu potrzeba zaimponowania żonie?

Władysław Wygnaniec nie dał swym dzieciom macochy, ale jego brat Mieszko III zwany Starym już tak. Pierwszą żoną księcia wielkopolskiego była królewna węgierska Elżbieta, z którą miał cztery córki i dwóch synów: Odona, urodzonego ok. 1145 r. oraz Stefana urodzonego ok. 1150 r. Gdy Elżbieta zmarła, Mieszko ożenił się (ok. 1151-1154) z księżniczką ruską Eudoksją. Została ona matką kolejnych córek oraz trzech synów: Bolesława (ur. 1159), Mieszka i Władysława Laskonogiego ${ }^{36}$. Mieszko Stary nie darzył sympatią synów z pierwszego związku i wyraźnie dał to odczuć, faworyzując młodsze dzieci, którym, jak pisał kronikarz, przyrzekł przekazać dziedzictwo ${ }^{37}$. Czy był to efekt braku pozytywnych uczuć Mieszka w stosunku do pierwszej żony i ciepłego stosunku do drugiej, czy też może decydowały cechy osobiste starszych synów? Czy Odon, bo Stefan zmarł wcześniej, ujawnił wcześniej jakieś ambicje polityczne, które mogły zagrozić jego przyrodnim braciom, albo toczył z nimi spory ${ }^{38}$, a Mieszko Stary brał wówczas stronę młodszych synów? Tego nie wiemy. Ale jeśli prawdziwe jest to drugie przypuszczenie, to nasuwa się obraz kłótni, która mogła zaistnieć pewnego dnia między dorastającym lub dorosłym synem (Odon mógł być starszy od pierworodnego syna księżnej Eudoksji nawet o więcej niż 15 lat) a czterdziestokilkuletnim lub starszym ojcem. Być może takie sprzeczki powtarzały się regularnie, a może ojciec i syn zaczęli się unikać? Odon obserwując zachowanie Mieszka III, słysząc o planach ojcowskich w stosunku do młodszego rodzeństwa, pozostawał jako dorosły książę wciąż bez własnego księstwa. Miał prawo czuć się wykluczonym i wyobcowanym z „nowej” rodziny ojca. Jak pisał S. Smolka:

W Wielkopolsce najstarszy syn Mieszków Odo stanął na czele powstania. I on bowiem miał z ojcem niezałatwiony obrachunek; syn królewny węgierskiej, pierwszej żony Mieszkowej, zazdrosnym okiem patrzył na braci przyrodnich,

36 O Mieszku III i jego rodzinie; K. Jasiński, Rodowód pierwszych Piastów, s. 233-242; K. Witkowski, Władysław Odonic, książę wielkopolski (ok. 1190-1239), Kraków 2012, s. 14.

37 Kronika polska mistrza Wincentego Kadłubka, wyd. M. Plezia, w: MPH. Seria Nowa, t. 2, Kraków 1994, s. 145.

38 M. Przybył, Mieszko III Stary, Poznań 2002, s. 94. 
synów ruskiej kniaziówny, którym ojciec więcej miłości okazywał, i nie taił się z tym, że któremu z nich pragnął zostawić po sobie panowanie. [Mieszko został] zmuszony do ucieczki wraz z trzema synami, którzy przeciw niemu zawiść Odona wzbudzili $[. . .]^{39}$.

Trzeba jednak zwrócić uwagę, że Mieszko stracił władzę (1177) wskutek ogólnego niezadowolenia z jego rządów. Odon był jednym z trybików, które wówczas do tego się przyczyniły. Bunt ten pozwolił jednak Odonowi, w umowie ze stryjem Kazimierzem, na otrzymanie części wielkopolskiej dzielnicy ojca ${ }^{40}$. Po powrocie Mieszka z wygnania nie mamy już informacji o złych relacjach między ojcem a jego pierworodnym synem. Wiemy natomiast, że Mieszko przywrócił Odona do łask ${ }^{41}$.

Przykład Odona pokazuje, że stryjowie i bratankowie potrafili się sprzymierzyć przeciw bratu i ojcu, jeśli było to dla nich obu z korzyścią polityczną. W drugiej połowie XII w. taki układ zaistniał również w rodzinie Bolesława Wysokiego, syna Władysława Wygnańca i Agnieszki. Pierwsza żona Bolesława, księżniczka ruska Zwinisława zmarła, ale pozostawiła syna Jarosława i córkę Olgę. Bolesław ożenił się po raz drugi (ok. 1160) ${ }^{42}$, a jego nowa żona miała zamiar wydziedziczyć pasierba. Jarosław jednak nie poddał się łatwo, zwłaszcza że jego stryj Mieszko Plątonogi również nie mógł porozumieć się z ojcem Jarosława, a swoim bratem. Bolesław i Mieszko, po powrocie z wygnania rozpoczęli wspólne rządy na Śląsku, ale Plątonogi zapragnął po pewnym czasie rozpocząć samodzielne władanie. Bolesław natomiast nie chciał do tego dopuścić. W podobnej sytuacji znalazł się Jarosław, który dodatkowo czuł się niepewnie wskutek działań macochy. Stryj i bratanek połączyli więc siły i podnieśli bunt przeciw Bolesławowi i jego żonie. Poparci zostali również przez ówczesnego seniora, Bolesława Kędzierzawego. Bolesław Wysoki i jego żona musieli uchodzić z kraju. Wsparł ich Fryderyk Barbarossa, najeżdżając na Polskę (1172). Bolesław Wysoki powrócił do władzy,

39 S. Smolka, Mieszko Stary i jego wiek, opr. i posłowiem opatrzył. J. Dobosz, Poznań 2011, s. 247-248.

40 Dyskusje, jaka była to część Wielkopolski m.in.: S. Szczur, Zmiany polityczne w Wielkopolsce w latach 1181-1195, „Roczniki Historyczne”, 46 (1980); M. Przybył, Władysław Laskonogi, książe wielkopolski 1202-1231, Poznań 1998; W. Baran-Kozłowski, Arcybiskup gnieźnieński Henryk Kietlicz (1199-1219). Działalność kościelna i polityczna, Poznań 2005; S. Pelczar, Władysław Odonic. Książę Wielkopolski, wygnaniec i protektor Kościoła (ok. 1193-1239), Kraków 2013.

41 M. Przybył, Władysław Laskonogi, s. 34.

42 K. Jasiński, Rodowód Piastów śląskich, Piastowie wrocławscy, legnicko-brzescy, świdniccy, ziębiccy, głogowscy, żagańscy, oleśniccy, opolscy, cieszyńscy i oświęcimscy, Kraków 2007, s. 63-64. 
ale wkrótce potem Mieszko Plątonogi i Jarosław otrzymali swoje dzielnice ${ }^{43}$. W ten sposób odsunięty przez ojca Jarosław przyczynił się do nowego podziału Śląska w drugiej połowie XII w.

$\mathrm{Na}$ tych kilku przykładach widać pewien schemat związany z wykluczeniami lub wyobcowaniami w rodzie Piastów, ale też ogólnie w wśród dynastów. Po pierwsze, każda matka chciała, aby jej potomek zasiadł na tronie. Po drugie, jeśli mężowie-ojcowie odsyłali żony z powodów politycznych lub z braku miłości, jeśli małżonki umierały, a ich miejsce zajmowały nowe żony i rodziły kolejnych synów, to pierworodni mogli czuć się zagrożeni w swojej pozycji dziedzica. Mogli też odczuwać ochłodzenie uczuć ojcowskich przenoszonych na ich młodsze, przyrodnie rodzeństwo. Po trzecie, efektem takiego rozwoju wydarzeń mogła być walka o władzę i swoje prawa, nawet jeszcze za życia ojca (np. Zbigniew, Jarosław, Odon) lub już po jego śmierci (Władysław Wygnaniec i jego bracia).

Należy jednak podkreślić, że - niezależnie od tego, czy ojciec i macocha faworyzowali wspólne dzieci, czy też tego nie czynili, czy chcieli odsunięcia od władzy dzieci z wcześniejszych małżeństw, czy też tego nie chcieli, tam, gdzie był więcej niż jeden potomek męski, nawet jeśli wszyscy byli dziećmi tej samej pary, i tak najczęściej dochodziło pomiędzy braćmi do rywalizacji o spadek. Najważniejszy więc czynnik to: dążenie do władzy lub do jej rozszerzenia, niezależnie od uwarunkowań rodzinnych. Sytuacja, w której ojca przeżył więcej niż jeden męski potomek, mogła oznaczać kłopoty dla państwa. Można jednak od razu podać tu również przykład Władysława Odonica, zwanego Plwaczem, który przeżył swojego ojca Odona, a przez niemal całe życie toczył walki ze stryjem Władysławem Laskonogim. Laskonogi natomiast przeżył swojego ojca, Mieszka III Starego jako jedyny jego syn. Dwaj Władysławowie, nie byli więc braćmi ani potomkami jednego ojca, ale książętami z dwóch różnych pokoleń. Byli jednak sprawcami blisko trzydziestoletnich lat walk wewnętrznych w Wielkopolsce (pierwszej połowa XIII w.).

Jakie więc znaczenie miały wykluczenia i wyobcowania? Przede wszystkim mogły przyspieszać spory rodzinne, powodując bunty i walkę o władzę jeszcze za życia panującego księcia-ojca.

43 Kronika polska, wyd. L. Ćwikliński, w: MPH, t. 3, Lwów 1878, s. 645; B. Zientara, Bolesław Wysoki - tułacz, repatriant, malkontent. Przyczynek do dziejów politycznych Polski XII w., „Przegląd Historyczny”, 62 (1971); N. Mika, Mieszko, syn Władysława Wygnańca, ksiązę raciborski i pan Krakowa - dzielnicowy władca Polski, Racibórz 2006, s. 133-134. 
Streszczenie: Tematem artykułu jest ukazanie, jakie skutki polityczne pociągały za sobą wyobcowania i wykluczenia członków dynastii Piastów. Koncentruje się on na przedstawieniu traktowania dzieci z wcześniejszych małżeństw przez ojców oraz przez macochy. Prezentuje znaczenie wyobcowań i wykluczeń młodych dynastów dla losów średniowiecznego państwa.

Słowa kluczowe: dynastia Piastów, wykluczenie, wyobcowanie, średniowiecze, polityka dynastyczna

\section{Bibliografia}

Galli Anonymi cronicae et gesta ducum sive principum Polonorum, wyd. K. Maleczyński, w: MPH, t. 2, Kraków 1952.

Kronika polska mistrza Wincentego Kadłubka, wyd. M. Plezia, w: Monumenta Poloniae Historica. Seria Nowa, t. 2, Kraków 1994.

Kronika polska, wyd. L. Ćwikliński, w: MPH, t. 3, Lwów 1878.

Z Damianiego żywotu św. Romualda, wyd. A. Bielowski, w: Monumenta Poloniae Historica, Lwów 1864.

Baran-Kozłowski W., Arcybiskup gnieźnieński Henryk Kietlicz (1199-1219). Działalność kościelna i polityczna, Poznań 2005.

Barbu Z., Problems of Historical Psychology, London 1960.

Barbu Z., Wprowadzenie do psychologii historycznej, Gdańsk 2003.

Benyskiewicz K., Książę Polski Władysław I Herman 1079-1102, Zielona Góra 2010.

Benyskiewicz K., Mieszko Bolesławowic 1069-1089. Źródła i tradycja historiograficzna, Kraków 2005.

Dworschatschek W., Władysław II Wygnaniec, Wrocław 1998.

Dymkowski M., Między psychologią a historią. O roli złudzeń w dziejach, Warszawa 2000.

Grodecki R., Zbigniew książę Polski, w: Studja staropolskie ku czci Aleksandra Brücknera, Kraków 1928.

Hoffer P.C., Czy psychohistoria jest naprawdę historia??, w: Psyche i Klio. Historia w oczach psychohistoryków, wybór, przekład i wstęp T. Pawelec, Lublin 2002.

Jasiński K., Rodowód Piastów ślaskich, Piastowie wrocławscy, legnicko-brzescy, świdniccy, ziębiccy, głogowscy, żagańscy, oleśniccy, opolscy, cieszyńscy i oświęcimscy, Kraków 2007.

Jasiński K., Rodowód pierwszych Piastów, Poznań 2004.

Kohut Th. A., Psychohistoria jako historia, w: Psyche i Klio. Historia w oczach psychohistoryków, wybór, przekład i wstęp T. Pawelec, Lublin 2002.

Krawiec A., Król bez korony. Władysław I Herman, książę Polski, Warszawa 2014.

Labuda G., Mieszko II król Polski (1025-1034). Czasy przełomu w dziejach państwa polskiego, Kraków 1992.

Labuda G., Zbygniew, w: Słownik starożytności słowiańskich, t. 7, Wrocław 1982. 
Lelewel J., Polska wieków średnich, t. 4, Poznań 1851.

Łaguna S., Rodowód Piastów, „Kwartalnik Historyczny”, 11 (1897).

Maleczyński K., Bolesław III Krzywousty, Kraków 2010.

Mause L. de, Niezależność psychohistorii, w: Psyche i Klio. Historia w oczach psychohistoryków, wybór, przekład i wstęp T. Pawelec, Lublin 2002.

Mazlish B., Podejście psychohistoryczne, w: Psyche i Klio. Historia w oczach psychohistoryków, wybór, przekład i wstęp T. Pawelec, Lublin 2002.

Mika N., Mieszko, syn Władysława Wygnańca, książę raciborski i pan Krakowa - dzielnicowy władca Polski, Racibórz 2006.

Pac G., Kobiety z dynastii Piastów. Rola społeczna piastowskich żon i córek do połowy xII wieku studium porównawcze, Toruń 2013.

Pawelec T., Wprowadzenie: psychohistoria w poszukiwaniu tożsamości, w: Psyche i Klio. Historia w oczach psychohistoryków, wybór, przekład i wstęp T. Pawelec, Lublin 2002.

Pelczar S., Władysław Odonic. Książę Wielkopolski, wygnaniec i protektor Kościoła (ok. 11931239), Kraków 2013.

Przybył M., Mieszko III Stary, Poznań 2002.

Przybył M., Władysław Laskonogi, książę wielkopolski 1202-1231, Poznań 1998.

Rosik S., Bolesław Krzywousty, Wrocław 2013.

Smolka S., Mieszko Stary i jego wiek, opr. i posłowiem opatrzył. J. Dobosz, Poznań 2011.

Spendel Z., Podmiotowość człowieka a psychologia historyczna, Katowice 1994.

Strzelczyk J., Bolesław Chrobry, Poznań 1999.

Strzelczyk J., Mieszko Pierwszy, Poznań 1999.

Szajnocha K., Bolesław Chrobry i odrodzenie sie Polski za Władysława Łokietka. Dwa opowiadania historyczne, Lwów 1859.

Szczur S., Zmiany polityczne $w$ Wielkopolsce $w$ latach 1181-1195, „Roczniki Historyczne”, 46 (1980).

Śliwiński B., Bezprym. Pierworodny syn pierwszego króla Polski (986-zima/wiosna 1032), Kraków 2014.

Tyc T., Zbigniew i Bolesław, w: tenże, Z dziejów Wielkopolski i Pomorza. Wybór prac, red. i posłowie J.M. Piskorski, Poznań 1997.

Witkowski K., Władysław Odonic, książę wielkopolski (ok. 1190-1239), Kraków 2012.

Zakrzewski S., Bolesław Chrobry Wielki, Kraków 2006, s. 321-322.

Zakrzewski S., Mieszko I jako budowniczy państwa polskiego, Kraków 2006.

Zientara B., Bolesław Wysoki - tułacz, repatriant, malkontent. Przyczynek do dziejów politycznych Polski XII w., „Przegląd Historyczny”, 62 (1971).

Zientara B., Mieszko II, w: Poczet królów i książąt polskich, red. A. Garlicki, Warszawa 1998. 